\title{
ANALYSIS OF QUESTIONS BASED ON THE COGNITIVE DIMENSIONS OF THE TIMSS IN MATHEMATICS TEXTBOOK CURRICULUM 2013 CLASS VII
}

\author{
Husna Nadhilah ${ }^{1}$, Asyril ${ }^{2}$, Azainil ${ }^{3}$ \\ 1 Mulawarman University, Samarinda, Indonesia \\ 2 Mulawarman University, Samarinda, Indonesia \\ 3 1Mulawarman University, Samarinda, Indonesia \\ 1hnadhilah01@gmail.com, 2asyril_1967@yahoo.com, ${ }^{3}$ azainil1966@gmail.com
}

\begin{abstract}
This study aims to analyze and describe the mathematics problem in the seven grade mathematics textbook K-13 based cognitive domain of Trends in International Mathematics and Science Study (TIMSS). Questions analyzed include competency test at the end of the chapter. The basis of this study is Indonesia's achievements in the TIMSS show that students' abilities are low. The type of this study is a descriptive qualitative research. Data collection method used by documentation. Documentation guide is classified in to cognitive domain of TIMSS. Data analysis technique of this research is data reduction, data display, and conclusion drawing/verification. The results of this study show that overall the questions in in the seventh graders mathematics textbook K-13 are not sufficient to train the level of students' thinking development in the cognitive dimension. The proportion of TIMSS cognitive dimensions in this book is uneven. This is indicated by the difference in the proportion of each domain. The domain that dominates the TIMSS cognitive proportion dimension is the domain that applies and knows the domain, and domain reasoning still has a very small proportion. This shows that questions within these textbooks are still lacking in improving logic and critical thinking skills and reasoning skills to create new problem-solving solutions. However, this book has provided questions to encourage and encourage students' thinking skills on domain knowledge and domain application.
\end{abstract}

Key words: Cognitive Dimension, TIMSS, Textbooks

\section{INTRODUCTION}

The progress of a country can be seen from the quality of its education. Quality education is very important to support the creation of intelligent human resources and have critical thinking skills. There are several international studies that regularly measure and compare progress in mathematics education in various countries, such as Trends in International Mathematics and Science Study (TIMSS).

Indonesia's score since participating in TIMSS in 1999 is 403, with an international average of 487, and ranks 34th out of 39 countries (Mullis, 1999). Furthermore, in 2003 it obtained a score of 411, with an international average of 467, and ranked 35th out of 46 countries (Mullis et al, 2004). In 2007 Indonesia obtained 397 with an international average of 500, and was in the 36th position out of 49 countries (Mullis, et al, 2008). The results of the 2011 TIMSS study, Indonesia ranked 38 out of 42 countries with a score of 386 and an international average of 500 (Mullis et al, 2012). The results of the 2015 TIMSS study, Indonesia is ranked 44th out of 49 countries with a score of 397 and an international average of 500 (Mullis et al, 2016). 
The TIMSS assessment is carried out based on two dimensions, the content dimension is used to determine the subject matter to be assessed, the content is in the form of numbers, algebra, geometry, data and opportunities. While the cognitive dimension is used to assess the thinking processes used by students related to knowing, applying, and reasoning. The proportion of abilities tested on the cognitive dimension in the TIMSS 2019 Assessment Framework reached $35 \%$ for domain knowing, $45 \%$ for domain applying, and 25\% for domain reasoning (Mullis \& Martin, 2017).

In addition to raising questions at a low-level cognitive level (remembering, understand, and apply) TIMSS also contains questions up to a high level of cognitive level (reasoning which includes the ability to analyze, generalize, synthesize, assess, and solve non-routine problems). Based on Indonesia's achievements in the event and TIMSS, it can be said that Indonesian students are not used to solving problems at a high level of cognitive level that require reasoning, argumentation and creativity.

This is one of the strong indicators that encourage the government to reform the 2013 curriculum. The difference between the implementation of the 2013 curriculum and the previous curriculum is the existence of student books that have been provided by the government as a compulsory school textbook for students. according to Sadjati (2018) One of the characteristics of good teaching materials (textbooks) is that it provides enough exercises/tasks for students to do on their own as a way to measure abilities. This exercise/task can be in the form of practice questions or competency test questions that must be completed by students. These questions are used as a tool to measure students' abilities and train students' cognitive aspects.

Although it has a very important role as a learning resource, not all textbooks have good quality and appropriate content. The difference in the quality of the textbooks used will have a different effect on students' abilities (Cahyono \& Adilah, 2016).

Given the importance of mathematics textbooks in the learning process, the mathematics textbooks used must be able to support and build learning activities and improve students' cognitive domains. In fact, there are still weaknesses in mathematics textbooks in Indonesia, one of which has not presented questions that are similar to the characteristics of TIMSS so that students lack experience in solving problems that require high-level thinking processes. According to Fajar et al, (2017) the scope of the cognitive dimension with the domain of knowing in the VIII Grade Mathematics Textbook has not matched the proportions tested on the TIMSS cognitive dimension. according to Lessani et al, (2014) Singapore, which always gets the highest math score in TIMSS 1999-2011, is due to a very well-developed curriculum, which causes the creation of textbooks in Singapore to contain the TIMSS domain. 
Considering Indonesia's achievement in the TIMSS international study study which shows the low ability of students and the importance of mathematics textbooks in the learning process. So it is necessary to conduct a study on the analysis of cognitive dimensions in mathematics books. Based on the background that has been explained, the researchers are interested in conducting research on "Analysis of Question Based on the Cognitive Dimensions of Trends in International Mathematics and Science Study (TIMSS) in the Mathematics Student Book Curriculum 2013 for Class VII".

The purpose of this study is to describe the characteristics of the cognitive dimensions according to TIMSS on the competency test questions in the mathematics student book curriculum 2013 class VII. Cognitive skills contained in mathematics textbooks need to be selected and analyzed first by the teacher according to students' abilities.

\section{METHOD}

This type of research is a qualitative research with a descriptive approach. With the data source in the form of the 2013 Curriculum Mathematics Student Book for Class VII Semester 1. The subject of the research is the competency test question for the 2013 Curriculum Mathematics Student Book for Class VII Semester 1 (Revised Edition 2017). The object in this study is the suitability of the cognitive dimensions in the 2013 Curriculum Mathematics Student Book for Class VII Semester 1 (Revised Edition 2017) with the TIMSS cognitive dimension.

Data collection in this study was carried out using the documentation method. Documentation guidelines are made based on the level of the TIMSS cognitive dimension and then put a check-list on each of the intended indicators. The cognitive dimension of TIMSS consists of three domains, namely the domain of knowing, the domain of applying, and the domain of reasoning.

The data analysis technique uses data reduction steps, data presentation, and drawing conclusions. Data reduction in this study was carried out by classifying competency test questions in books based on the cognitive dimensions of the 2019 TIMSS. The results of the data reduction obtained would be calculated and percentages were made for each domain and cognitive aspect. Then it is presented in tabular form, after that a diagram is made to make it easier for researchers to draw conclusions so that it can be seen the characteristics of the cognitive dimensions on the competency test questions in the mathematics student book 2013 curriculum class VII.

Checking the validity of the data in this study was done by triangulation of sources. Source triangulation is done by checking the data from the analysis that has been obtained by researchers through several sources (Sugiyono, 2016). 


\section{RESULT AND DISCUSSION}

Based on the results of the analysis of the characteristics of the cognitive dimensions in the form of domain levels and cognitive aspects contained in the competency test questions in the Mathematics Book Class VII Semester 1 Curriculum 2013 Revised 2017 which is the subject of research, as attached in Table 1, the data obtained that The highest domain of knowing is found in the questions of competency test 1 and competency test 3 with the acquisition of each percentage of $50 \%$. The questions that reach the highest domain applying are in competency test questions 2 with a percentage of $75 \%$. While the questions that reach the highest reasoning domain are in the 3rd competency test question of 33\%.

Table 1. Results of Cognitive Domains Analysis Recapitulation

\begin{tabular}{ccccccc}
\hline $\begin{array}{c}\text { Competence } \\
\text { test }\end{array}$ & Knowing & $(\%)$ & Applying & $(\%)$ & Reasoning & $(\%)$ \\
\hline 1 & 15 & $50 \%$ & 13 & $43.33 \%$ & 2 & $6.67 \%$ \\
2 & 8 & $22.22 \%$ & 27 & $75 \%$ & 1 & $2.78 \%$ \\
3 & 15 & $50 \%$ & 5 & $16.67 \%$ & 10 & $33.33 \%$ \\
4 & 12 & $34.29 \%$ & 23 & $65.71 \%$ & 0 & $0 \%$ \\
Semester 1 & 11 & $37.93 \%$ & 16 & $55.17 \%$ & 2 & $6.90 \%$ \\
\hline
\end{tabular}

Table 2. Number and Percentage of Cognitive Domains

\begin{tabular}{lccc}
\hline \multicolumn{4}{c}{ Competency Test on Mathematics Book Class VII Semester 1 } \\
\hline Cognitive Domain & Knowing & Applying & Reasoning \\
Number of Domains & 61 & 84 & 15 \\
Percentage & $38.13 \%$ & $52.50 \%$ & $9.38 \%$ \\
\hline
\end{tabular}

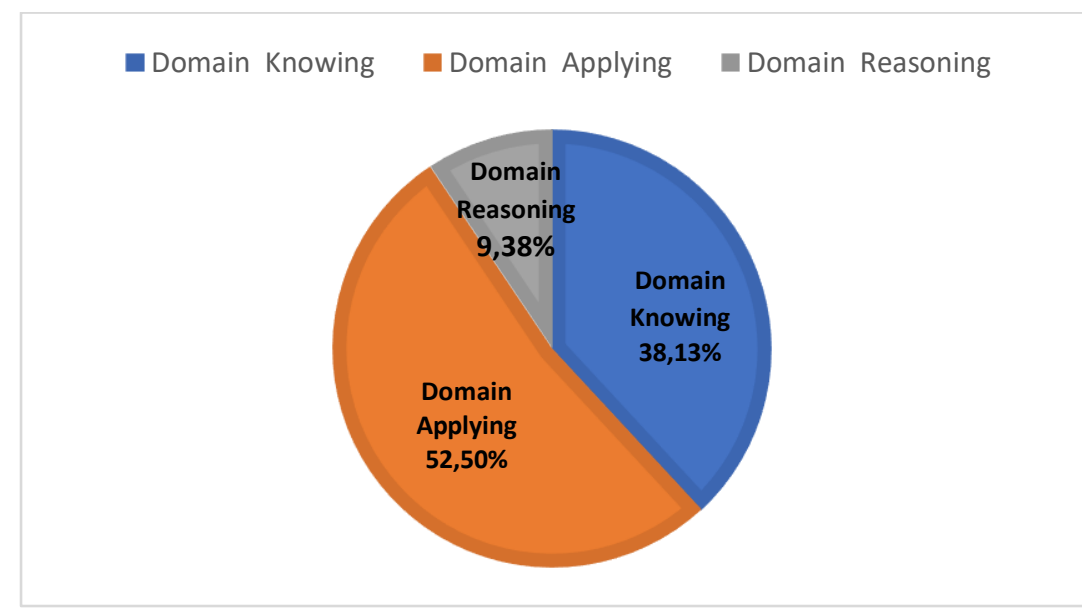

Of the 161 questions in the book, 61 questions were obtained which were the cognitive level in the knowing domain with a percentage of 38.13\%, 84 questions in the domain applying with a percentage of $52.50 \%$, and 15 questions in the reasoning domain with a percentage of $9.38 \%$. 
It can be seen that the questions in the book contain a lot of represent aspects, namely $20.54 \%$ compute $20.09 \%$, implement $16.07 \%$, determine $13.84 \%$, recognize $8.93 \%$, classify $8.48 \%$, recall of $4.02 \%$, integrate of $3.57 \%$, analyze of $3.13 \%$, evaluate, draw conclusions, and justify each of $0.45 \%$, while there are no questions that contain aspects of retrieve, measure, and generalize.

The cognitive dimensions in the mathematics textbook for class VII semester 12013 curriculum do not match the proportion of abilities tested on the TIMSS cognitive dimension, where for the domains of knowing and applying it exceeds the proportions tested. Questions with domain knowing are questions with low-level thinking skills, having characteristics of questions that require basic knowledge such as remembering and understanding facts, mathematical concepts and procedures that will be used in problem solving. Problems with domain applying are questions with moderate-level thinking skills, have the characteristics of questions that apply basic knowledge as a tool to solve problems.

While the reasoning domain is much less than the proportion tested by TIMSS. Problems with the reasoning domain are questions with high-level thinking skills, have characteristics of questions that involve logical and critical thinking skills, and reasoning skills that can be used to get new problem solving solutions.

The highest aspect is the compute aspect, which is a question that completes procedures with addition, subtraction, multiplication, division, or a mixture of whole numbers, fractions, decimals or whole numbers. This shows that students in Indonesia are familiarized with low-level thinking questions, especially counting. As shown in the score obtained in the TIMSS study results which reflect that the ability of Indonesian students is low and below the international average, because they are only able to understand the basics of integers and decimals, can perform basic calculations and can read simple diagrams.

The unmatched proportion of questions on the cognitive dimension, where questions with domain knowing and domain applying dominate, and domain reasoning still has a very small proportion, indicating that students in Indonesia still have low to moderate-level thinking skills, limited to basic knowledge and its application. This is in line with according to Widayanti \& Kolbi (2018) which states that the ability of Indonesian students is still low, because they are not accustomed to solving problems that require higher-order thinking skills. In addition, according to Zakiah \& Khairi (2019) cognitive domain has an influence on mathematics achievement.

The questions in the math book for class VII semester 1 of the 2013 curriculum have attempted to train and encourage students' thinking skills when viewed from the percentage of domain knowing and domain applying, although the proportion of domain reasoning needs to be 
added, to match the objectives of learning mathematics according to BSNP, namely, mastering reasoning skills.

\section{CONCLUSION}

Overall, the questions in the textbooks for seventh grade mathematics students in semester 1 of the 2013 Curriculum are not sufficient to train students' thinking development levels on the cognitive dimension. The proportion of cognitive dimensions of TIMSS in this book is uneven. This is indicated by the difference in the percentage of each domain. Domains that meet the proportion of TIMSS cognitive dimensions are the domain applying and the domain knowing, while the reasoning domain still has a very small proportion.

This shows that the questions in the book are still lacking in honing logic and critical thinking skills, as well as reasoning skills to find solutions to new problems. However, this book has provided questions to encourage and encourage students' thinking skills on domain knowledge and domain application. 


\section{REFERENCES}

Cahyono, B., \& Adilah, N. (2016). Analisis Soal dalam Buku Siswa Matematika Kurikulum 2013 Kelas VIII Semester I Berdasarkan Dimensi Kognitif dari TIMSS. Jurnal Review Pembelajaran Matematika, 1(1), 86-98. https://doi.org/10.15642/jrpm.2016.1.1.86-98

Fajar, M. Y., Harahap, E., Sukarsih, I., Rohaeni, O., \& Suhaedi, D. (2017). Implementation of Lesson Study on Integral Calculus Course. Proceeding The 8th International Conference on Lesson Study (ICLS), April, 400-407. ISBN 978-602-98097-8-7

Lessani, A., Yunus, A. S. M., Tarmiz, R. A., \& Mahmud, R. (2014). Why Singaporean 8th grade students gain highest mathematics ranking in TIMSS (1999-2011). International Education Studies, 7(11), 173-181. https://doi.org/10.5539/ies.v7n11p173

Mullis, I. V. S., Martin, M. O., Foy, P., \& Hooper, M. (2016). TIMSS 2015 International Results in Mathematics 2016.

Mullis, I. V. S., Martin, M. O. (2004). TIMSS 2003 International Matematics Report. 33-55.

Mullis, I. V. S., Martin, M. O. (2008). TIMMS 2007 Chapter 1.

Mullis, I. V. S., Martin, M. O. (2012). TIMSS 2011 International Results in Mathematics. https://doi.org/10.1037/030262

Mullis, I. V. S., Martin, M. O. (2017). TIMSS 2019 Mathematics Assessment Framework. TIMSS 2019 Assessment Frameworks. http://timssandpirls.bc.edu/timss2019/frameworks/

Mullis, I. V. S. (1999). TIMSS 1999 Mathematics Report.

Sadjati, I. . (2018). Hakikat Bahan Ajar. Pendidikan, 3(1), 1-62. https://doi.org/10.1017/CB09781107415324.004

Sugiyono. (2016). Metode Penelitian Pendidikan Pendekatan Kuantitatif, Kualitatif, dan R\&D. Bandung: Alfabeta.

Widayanti, E., \& Kolbi, I. A. (2018). Analisis Kesalahan Siswa dalam Mengerjakan Soal TIMMS untuk Kategori Penalaran. Jurnal Review Pembelajaran Matematika, 3(1), 76-85. https://doi.org/10.15642/jrpm.2018.3.1.76-85

Zakiah, Z., \& Khairi, F. (2019). Pengaruh Kemampuan Kognitif Terhadap Prestasi Belajar Matematika Siswa Kelas V Sdn Gugus 01 Kecamatan Selaparang. Jurnal El Midad, 11(1), 85100. https://doi.org/10.20414/elmidad.v11i1.1906 